\title{
Merchants, SCHOLARS AND languages: The CIRCULATION OF LINGUISTIC KNOWLEDGE IN THE CONTEXT of the Dutch East Inda Company (VOC)*
}

\author{
Anna Pytlowany \& Toon Van Hal
}

Universiteit van Amsterdam \& KU Leuven

\section{Résumé}

Cet article analyse la contribution de la Compagnie néerlandaise des Indes orientales (VOC) sur la circulation des connaissances linguistiques. Il présente tout d'abord quelques « linguistes de terrain » néerlandais oubliés de nos jours et le sort de leurs œuvres en Europe. Puis, dans un second temps, il adopte la perspective inverse en examinant dans quelle mesure les érudits basés en Europe invitèrent des membres de la VOC à leur transmettre des informations sur les langues du monde.

\section{Mots-clés}

circulation des savoirs linguistiques, linguistique missionnaire, recueils multilingues du Notre Père, VOC

\begin{abstract}
This paper offers an initial exploration of the impact of the Dutch United East India Company (VOC) on the circulation of linguistic knowledge. After presenting some forgotten Dutch linguistic fieldworkers who operated overseas, and after examining the fate of their works in Europe, we will examine in a second part the degree to which Europe-based scholars actively solicited VOC-actors to pass on information about the world's languages.
\end{abstract}

\section{Keywords}

Circulation of linguistic knowledge, Lord's Prayer translations, missionary linguistics, VOC

* We are much indebted to Catherine Sambrook (King's College London, Foyle Special Collections Library) and to Rebeca Fernandez Rodriguez (Amsterdam University) for facilitating our access to unpublished materials. In addition, we would like to thank the anonymous peer reviewers, the members of the editorial board as well as Jos Gommans for their remarks on earlier drafts of this paper. 
The establishment of the Dutch United East India Company (Verenigde Oostindische Compagnie or VOC) in 1602 has had a far-reaching impact on the position of the Netherlands in the world. To a lesser degree, it has also led to a more globalised position of the Dutch language. Conversely, the VOC has also affected, to various extents, the development of several indigenous cultures and their languages in Africa and in the Far East. This is why the activities of this commercial company, essentially the world's first multinational, can take centre stage in answering a wide range of research questions in the fields of both language history and the history of linguistics. One could investigate, for instance, whether the manuscript grammars and dictionaries that emerged against the background of the VOC could cast additional light on the pronunciation of 17th- and 18th-century Dutch, and on its overall attitude to the use of loanwords. Scholars interested in African or Asian languages might be eager to explore to what extent these sources contain interesting historical data of ill-documented languages. Historiographers of linguistics, in turn, will be interested in examining the specifics of Dutch as a metalanguage for describing non-European languages (see Pytlowany \& Zwartjes Forthcoming for a first exploration). This paper, however, seeks to answer yet another question, since it aims to explore the relevance of the VOC in the circulation of knowledge on the world's languages. ${ }^{1}$

It comes as no surprise that VOC activities have been examined primarily by scholars interested in early modern global trade and in international politics, including warfare. However, its international network also gave way to forms of exchange and transfer other than purely commercial ones. Recent book-length scholarly work scrutinising the potential of the VOC's infrastructure for acquiring and circulating knowledge include the collected volumes edited by Blussé \& Ooms (2002), Huigen, De Jong \& Kolfin (2010) and Friedrich, Brendecke, \& Ehrenpreis (2015). Although some contributions are devoted to linguistic matters (viz. Den Besten 2010 and Maier \& Van der Putten 2002), an overall investigation into knowledge strategies adopted by VOC linguistic 'fieldworkers' and into their interaction with Dutch scholars is lacking. This paper brings together results obtained in recent research papers and a number of new or underexplored primary sources. Throughout the paper, special attention will be paid to the relation between the circulation of linguistic knowledge in the framework of VOC activities on the one hand and the VOC's general knowledge management on the

1 As such, this joint paper sits at the crossroads of the research interests of both authors: A. Pytlowany is finishing a PhD project entitled 'Dutch VOC linguistics through the prism of the first grammar of Hindustani by J.J. Ketelaar (1698)' and T. Van Hal is currently supervising a research project titled 'Evolving views on the world's languages in a globalizing world (1540-1840): information growth, conceptual shifts, scholarly networks in the circulation of linguistic knowledge' (2015-2019, funded by KU Leuven research council). 
other. Taken together, this will result in a first, and thus necessarily kaleidoscopic and exploratory, assessment of the general relevance of VOC activities, be it direct or indirect, in the circulation of linguistic knowledge and its reception in the Early Modern European Republic of Letters. Our chronological focus is on a very prolific period of the multinational, namely between 1680 and 1720 .

\section{THE VOC AND ITS ATTITUDES TOWARDS INDIGENOUS LANGUAGES}

By fitting about 4700 ships that have transferred almost 1 million passengers, the VOC was the most successful trading company in the 17th and 18th centuries (see Gaastra 2007 for a general introduction). The Company's growth and commercial success was initially stimulated by it winning a monopoly on the spice trade. Later, intra-Asian trade between its establishments became a source of huge supplementary income. At the end of the 17th century, tea from China, Arabian coffee and textiles from India captured the imagination of people in Europe, which led to significant market growth. Hence, the VOC also contributed to what Jan de Vries has labelled the 'Industrious Revolution', a period of economic growth driven by consumer demand. However, with increasing competition and wars at home, VOC's profits dropped while administrative expenses and corruption grew. Eventually, the Company was officially dissolved in 1800 .

From a geographical point of view, the map of VOC's areas of influence and activity remained very patchy: it stretched from a colony in the African Cape to a small-scale trade post on a minuscule artificial island off the coast of Japan. Whereas native people in Indonesia suffered from unabashed Dutch colonisation in the worst sense of the word, Dutch merchants exerted far less power and supremacy in other long-term posts overseas. They themselves distinguished three categories of administration in Asia: first, the cities and territories obtained by conquest (such as Batavia, today's Jakarta, and Malakka); second, rather large-scale factories, with (exclusive) trade contracts with local rulers (Ayutthaya, the royal capital of Siam, is an example); third, small-scale posts (e.g. Nagasaki and Canton), which were strictly controlled by local authorities (Blussé 2008, p. 34-35).

Considering these various local contexts, it is not surprising that the VOC did not establish a unified language policy. Whereas the Portuguese, English and Spanish colonial powers eventually succeeded in imposing their own languages onto the indigenous populations, Dutch became a major language only in Suriname and South Africa (Willemyns 2013, p. 196; 212-214). One Early Modern Dutchman ascribed this to the 'congenital modesty' that was so typical of the Dutch, whereupon he, quite ironically, immediately suggested that it was also possible that Dutchmen were more talented in mastering foreign languages thanks to their 'particular ingenuity' (Maier \& Van der Putten 2002, p. 101). Present-day scholars, 
startled by this relatively modest impact of Dutch, have argued that the relatively small native language communities in the Americas and in Africa were more likely to adopt the language of the colonial powers through the larger influx of European emigrants (see Willemyns 2013, p. 212-214). Asian communities, on the other hand, proved to be more resistant as they remained powerful in both numbers and organisation (Groeneboer 1998, p. 21-22). Moreover, in several new Dutch settlements, the language of another European power had become a well-established lingua franca. Both the 'higher variety' of Portuguese and Portuguese-based Creoles were used in several Asian trade posts (Schouten 2010, p. 351-353).

Willemyns (2013, p. 213) has stressed how VOC strategies in general were highly characterised by pragmatism, and that the same holds true for the VOC language policy. This does not imply that there have not been any attempts to introduce Dutch as a general language for education and religion. As early as 1611, VOC published Sovrat A.B.C., a basic introduction to the Latin alphabet accompanied by a selection of Christian prayers for speakers of Malay. Other works and catechisms followed (cf. Thianto 2014; Groeneboer 1993, p. 43-45). In India, Dutch seminaries were established to educate children in both Dutch and the local language (Tamil or Sinhalese). In turn, they would be able "to teach and educate others for the Company's benefit"'. One of the first governors of Colombo, Ryckloff van Goens (1659-1675), introduced some radical means to promote learning Dutch. Groeneboer (1993, p. 73) illustrates how slaves who were not able to speak Dutch had their hair cut off as a penalty. In many other cases, VOC officials tended to hire local interpreters and even established translation departments (Schouten 2010, p. 349-350). However, Early Modern tradesmen knew the risks of being entirely dependent on interpreters, even to the point that it became a topos in contemporary treatises presenting the 'perfect ambassador': an interpreter could always deliberately twist words (see Sutherland 2010). The pragmatic solution applied by Dutch commanders in Golconda (India) consisted in "mastering Telugu to that extent that they could express their opinion as well as control the interpreters' job" (Van Dam 1927-1954, p. II.2, 164). Thus, some degree of knowledge of the local languages was a daily necessity for ordinary employees. Annette Fleischer mentions how Jan Wilhelm van Grevenbroek (1644-1726), who will be referred to again in another section, recommended that his fellow settlers in the Cape gain a basic knowledge of the local Khoi language, commenting that the "Dutch ought

2 "alsmede eenige van deselve mettertijt tot die bequaemheyt te brengen om andere te kunnen leeren en onderwijsen voor den dienst van de Compagnie" (Van Dam 1927-1954: IV, 19). Meuwese (2010, p. 117-118) describes how native children were sent to the Netherlands for an intensive Protestant education, where they eventually lost their mother tongue.

3 "[...] sooveel van de Tellingase taal verstaande, dat se haar meyningh kunnen uytdrucken, en begrypen, off het de tolcken in die taal wel doen". 
to be aware how firm a bond of union a common language is, and how powerful a means it is of keeping peoples loyal and peaceful" (quoted in Fleischer 2010, p. 260). Although imposing one's language on the native population can be seen as a means of 'overpowering' this population, the company also saw a danger in 'Dutchifying' the settlements: once these natives had acquired Dutch, they would be able to make active use of this language precisely against the colonising forces (Willemyns 2013, p. 197). In their relations with Dutch traders, the Japanese authorities had a similar concern about the power of language. They were so eager to protect their own language that all the dealings with the Dutch were conducted via a team of 150 interpreters of different ranks, whose jobs were hereditary. This was enough "to prevent the Dutch from having to learn Japanese" (Goodman 2000, p. 20). Hence, a Dutch VOC-official was forced to leave Japanese soil in 1718, as he was said to have a too profound knowledge of the language (Feenstra Kuiper 1921, p. 173).

The following section will explore to what extent the Dutch activities of learning indigenous languages also resulted in the production of written learning aids.

\section{THE VICISSITUDES OF VOC GRAMMARS AND DICTIONARIES}

Reading the collected volume by Blussé and Ooms (2002) - Knowledge and company: the VOC and modern science - led Van Renssen (2002) in a newspaper review to the somewhat puzzling and surprising finding that all knowledge about Asia acquired against the background of Dutch commercial enterprises was obtained in spite of - rather than thanks to - the policy of the VOC. A much-quoted lament of VOC director Nicolaas Witsen (1641-1717), whose seminal contribution to scholarship will be discussed in the following section, confirms this judgment and offers an insider's view: "Why does your Honour ask about scholarly curiosity in India? No Sir, it is only money and no knowledge which our people are after, which is regrettable."

All the same, the overseas VOC activities resulted in a wide range of published and unpublished linguistic materials. The earliest wordlists and a phrasebook in Malay and Malagasy were written by Dutch merchants and explorers, Peter Willemsz. Floris van Elbinck and Frederik de Houtman (1571-1627), respectively (cf. Lombard 2001; Bertrand 2013; Schouten 2010, p. 349). Many other works in Malay followed. The second best described language was Sinhala. The first

4 "Wat vraegt UwelEd. na de geleerde curieusheyt van Indiën? Neen Heer, het is alleen gelt en geen wetenschap die onse luyden soeken aldaer, 't gunt is te beklagen." Translation by Huigen $(2010$, p. 8). See in this respect also Voltaire's observation in a 1776 letter to Jean-Sylvain Bailly: "nos compagnies des Indes n'ont pas été des Académies des sciences" (Bailly \& Voltaire 1777, p. 5; reference to this letter is also made by Rietbergen 2002, p. 164). Meuwese (2010, p. 107) highlights that "the Dutch were much more concerned about bringing Protestant Christianity to non-Europeans than commonly believed." 
Dutch grammar of Tamil (1672), compiled by a Calvinist minister called Philippus Baldaeus (1632-1672), who preached in Ceylon and Malabar from 1655 to 1666, was an insert in his 1672 Naauwkeurige Beschryvinge der Indische Kusten Malabar ende Choramandel. Formosan languages Siraya and Favorlang, now extinct, owe their first descriptions to the efforts of Dutch ministers in Taiwan (Klöter 2008); the first word list of Korean comes from a Dutchman (see below). Europe's earliest published translation from Sanskrit was prepared (via Portuguese) by Abraham Rogerius (ca. 1609-1649; see Neill 2004, p. 380); the first grammar of Hindustani was composed by VOC merchant and ambassador Ketelaar (1659-1718). ${ }^{5}$

Before discussing the many challenges related to this text corpus, it might be worthwhile to reflect on how 'VOC linguistics' relates to colonial and missionary linguistics. When it comes to the circulation of knowledge in general, one has to keep in mind that for both the missionaries and the commercial companies, conducting empirically-driven scientific and scholarly research was not the first objective. Nor were they interested in foreign languages in their own right. Profit was the VOC's very reason of existence, not science or scholarship. Nevertheless, both missionaries and merchants came to understand that local knowledge was often a crucial prerequisite for obtaining their respective objectives. In the light of ongoing disciplinary discussions on differences and convergence points between both colonial and missionary linguistics (Stolz \& Warnke 2015), we would argue that the VOC actors and authors could be seen as occupying an in-between position in the spectrum between missionary and colonial linguistics. In stark contrast to Church-backed ventures such as Propaganda Fide's Polyglot Press in Rome, which systematically commissioned, edited and printed dictionaries and grammars, there are no traces of the Dutch East India Company itself encouraging such linguistic endeavours. Whereas Catholic missionaries were compelled to master indigenous languages to convert masses of souls to Christianity, merchants in general could rely on local interpreters for daily communication. However, one should not forget that the VOC also had to observe some religious tasks, as the organisation was officially obliged to provide financial support for the Calvinist ministers, whose primary job was to serve the Dutch expat community, on the ships as well as in their posts. Many ministers, however, considered it appropriate to go beyond this task by attempting to win new souls for Christ. Hence, schoolmasters and Calvinist ministers dependent on the Company's subsidy often tried to persuade the VOC directors of the need to publish a grammar or a dictionary of a local language. After all, any educational and linguistic activity would eventually benefit the Company, as they quickly learnt to highlight.

5 Pytlowany forthcoming. See also Tej Bhatia's and Kazuhiko Machida's contribution in the present volume. 
A proper survey of all the Dutch linguistic documents composed either by VOC employees or under the auspices of the Company has yet to be done. The extensive bibliography by Landwehr et al. (1991) contains 1674 publications relating to the Dutch East India Company, one chapter of which is devoted to printed Dictionaries and Grammars (449-457), but without including texts that exist only in manuscript form. A full survey should contain the names of the authors, whether or not their work survived to our times, a list of languages that were studied or described, as well as all secondary literature and studies done in recent years. Such an endeavour is, however, plagued with difficulties. First and foremost, there is a serious problem of information loss. Amateur philologists in the areas where VOC had no deeper interest in the local language beyond immediate commercial contacts, had to work at their own instigation. Of all linguistic works composed, many have been lost, and all that is left today are occasional allusions in contemporary literature, historical documents and private correspondence. A good example is what one could style 'the case Van Grevenbroek' for the published Hottentot remnants in early 18th-century scholarship (Hottentot is a frequently-used term for 'Khoi (khoi)', which is a meanwhile extinct language spoken in present-day South Africa). Both Hiob Ludolf (1624-1704) and Gottfried Wilhelm Leibniz (16461716) had specimens of this language in their possession. Recently, some scholars have attempted to reconstruct the original provenance of these sources. Groenewald (2004) argues that the provenance of the Lord's Prayer can be traced to Jan Wilhelm van Grevenbroek, who noted it with the help of a certain captain Dorha. Twidle (2013, p. 138) presents other scholarship suggesting that Van Grevenbroek was a VOC official who attached much importance to the study of the indigenous cultures (cf. also Kolbe 1727, p. 421 on whom see also Huigen 2009). The unfortunate fact is that there are several good reasons to believe that van Grevenbroek composed a very detailed and worthwhile description of Khoi culture, but that the manuscript never reached the printer and is now irretrievably lost.

The linguistic works that survived to our times are scattered in libraries and archives around the world. Every now and then, a new manuscript surfaces and some are published. Paranavitana (2013), for instance, is an edition of an unknown 1695 Dutch-Sinhala dictionary by Simon Cat. Thanks to recent digitisation efforts, new resources are becoming available to researchers almost daily. Let us, by way of example, focus on the Special Collections section of Utrecht University Library as a representative case. Home of one of the oldest chairs of Oriental languages in the Netherlands, thus warranting generations of eminent professors in this field, the library's online collection exhibits four beautifully digitised objects that can be related to VOC: besides Houtman's Spraeck ende woord-boeck, in de Maleysche ende Madagaskarsche talen printed in 1603, 
there are three manuscripts: a grammar and vocabulary of Hindustani and Persian by Ketelaar (Ms 1478: Instructie of onderwijsinghe der Hindoustanse en Persiaanse taalen); a grammar of Tamil (Ms 1479: Poginge om net te beschrijven d'eygenschap, kragt en het gebruyk van de Malabaerse vocalen, letteren); and Vocabularium Formosanum (Ms 1483), a wordlist from Taiwan with Dutch-Formosan conversations, written on Chinese rice paper. In the catalogue, all three manuscripts are marked as legated by Adriaan Reland (Hadrianus Relandus, 16761718). The curious coincidence is that all three of them are anonymous due to missing title pages and, in Ketelaar's case, the inking out of the author's name. Vocabularium Formosanum is a title added later in a different ink, together with the column names Formosana and Belgica, possibly written in Reland's own hand.

The issue of anonymity is a persistent one in the history of VOC linguistics. For instance, a 17th-century Persian-Hindustani-Dutch vocabulary kept in Leiden University Library (Ms 589) lacks a proper title page, the name of the author and the date. A Malay grammar from the Biblioteca Nazionale Marciana (Ms Or 237) mysteriously lacks the title page and any information on the author or date. A second manuscript copy of the same work, preserved in the State Library of New South Wales (Ms A637), bears a beautifully written title page stating Herbert de Jager (1634-1694) as its author, as well as the date 1683, leaving no doubts about the authorship of the Marciana copy. Similarly, the two later copies of Ketelaar's Instructie have his name on the title page, yet the apparently earlier one in the possession of Reland, did not.

How can one explain this striking number of anonymous works? A letter from professor Gijsbert Cuper (1644-1716) to diplomat Pieter Valckenier (1638 or 1641-1712), described by Marion Peters, suggests one possible reason. When visiting Witsen's place, Cuper

saw two volumes of De Jager's sketches of plants and herbs of Java. Witsen had on that occasion also told him that De Jager had been in the habit of sending him large quantities of drawings of flowers, plants, men, women, houses, implements, utensils, etc., but that the Company had seized them, as it had previously done with De Jager's Arabic manuscripts. Now everything was held at the VOC's offices, locked away in a chest. (Peters 1989, p. 113)

If even the chief's overseas 'shipping orders' could have been seized by the Company, would this imply that the Company's secrecy policy might be the reason why linguistic works had to be anonymised if they were to reach scholars in the Republic? Maybe such measures had to be taken to protect works from being identified as 'belonging' to the Company? In contrast, the works officially received by the VOC or acquired via legal routes such as Joannes Ruëll's (1662?-1701) Grammatica, of Singaleesche Taal-Kunst, proudly exhibits the name of the author and the date of the Opdracht ('dedication'). More than once, and especially in the 
early years, the VOC explicitly prohibited publishing any research results, out of fear that concurring associations could also take advantage of them. In contrast to the scholarly Republic of Letters, characterised by its members' willingness to share information, the VOC's products of knowledge - by definition subservient to making money ${ }^{6}$ - were often destined to internal use only (see Van Berkel 1998, p. 146; Naarden 2010). Even if the spread of scholarship was actively hampered by some VOC officials, it still was unfeasible to intercept all kinds of specimens and curiosities that were imported from Asia to Europe - illegal or not (see Van Berkel 1998, p. 146). Rietbergen (2002, p. 166) however shows that some VOC directors understood the importance of 'public relations' and 'image-building', resulting in a more liberal access policy to VOC archives from time to time.

Certainly, the reasons for removing all identifiable elements from the manuscripts may have been of a far more mundane and self-serving nature. What was easier than taking an anonymous text from a faraway place and publishing it under one's own name? One of the authors famous for his reluctance to quote his sources was Dutch minister François Valentijn (1666-1727), who was besides being author of a monumental history of the VOC also involved in a dispute about the authorship of a Bible translation into Malay. In addition, he was accused of plagiarising a Malay dictionary and suspected of illegally acquiring de Jager's papers after his death (see Beekman 1988, p. 67, 70). Whether these latter allegations are true or not, it is a fact that the above-mentioned anonymised copy of De Jager's Malay grammar comes ex libris Francisci Valentini.

Many questions on provenance and authorship of the extant works can be answered by studying them not only as texts but also as physical documents. There is now an arsenal of methods to analyse the material features, ranging from classical bibliographical queries based on bookseller plates and auction or library catalogue numbers, over palaeographic and watermark studies, to more sophisticated scientific tests for paper fibre and petrographic analysis of blotting sand, XRF tests of inks and pigments, and hyperspectral imaging ${ }^{7}$. The metalanguage used can throw some light on the intended readership. The linguistic materials produced by Dutchmen against the backdrop of VOC activities were mostly published entirely in Dutch. We are not aware of authors explaining why they had opted for Dutch as a metalanguage. It seems safe to state that the intended audience of works published were Dutch merchants, whereas authors writing in Latin aimed

6 Rietbergen (2002, p. 166) argues that precisely their profit-driven attitude inspired some VOC servants to make money from their adventures in the Far East by composing travelogues. Also Brendecke \& Friedrich (2015, p. 4-5) adopt a more positive attitude towards the knowledge policy of the VOC.

7 See Pytlowany $(2014,2015)$ for a general overview and some examples. The name of Ketelaar as the author has been confirmed by a Hyperspectral Imager study instigated by Anna Pytlowany in 2011. 
to reach a more international and scholarly oriented readership. Once appointed as professor in oriental languages in the German city of Lingen, George Henric Werndly (1694-1744), who as a minister in Padang (Batavia) composed a Dutch grammar of Malay (Maleische Spraakkunst, uit de eige schriften der Maleiers opgemaakt, 1736), did not fail to highlight that he was not used to hold speeches in Latin (Werndly 1740, p. 620). We however see that some authors include Latin elements in their learning aids. In order to avoid misunderstandings, every Dutch grammatical term in Ruëll's grammar is followed by its Latin translation in brackets, while Ketelaar included some Latin chapter titles such as "Ad lectorem benevolum", etc. The case of Ketelaar is especially telling, as his text is directly modelled on, and in parts even literally translated from, an earlier Latin grammar (Pytlowany Forthcoming), probably to make it accessible to Dutch merchants. In 1743, it was - rather ironically - retranslated into Latin by Professor David Mill (Millius) (1692-1756) from Utrecht.

Let us end this exploratory overview with one of the exceptional success stories in VOC-driven circulation of linguistic knowledge, even if such characterisation is in need of further qualification. The Opdracht ('dedication') of the above-mentioned Sinhala grammar by Johannes Ruëll, presented to the VOC direction in 1699, points out the need for a Sinhala manual for future ministers in Ceylon. The manuscript was personally taken charge of by Nicolaas Witsen, who commissioned a printer from Amsterdam, François Halma (1653-1722), to publish it. As it turned out, it was to be the first book with Sinhala letters printed in Europe. The process took a long nine years (although such dates are not entirely reliable) before Grammatica, of Singaleesche Taal-Kunst finally came out in 1708. Its edition was, however, so limited that even the copy in the St. Petersburg library, presumably a vestige of Witsen's Russian connections, is a hand-made copy of the actual book rather than a print (De la Croze 1724, p. 429 however refers to the grammar). Two manuscript copies of the book are still extant in the Netherlands, both of which were likely used in the preparation of the printed book, one as a basis for the text edition, and the other used by the craftsman who cut wooden blocks of Sinhala characters. Although in the manuscripts Sinhala words are spelled only with Sinhalese characters, the final book is enriched with Roman transliteration, which implies that an expert in non-European languages must also have been involved in the process. Ruëll's grammar may well have been a rare success story in the sense that it attained funding and publishing in Europe. However, there was no happy ending in Sri Lanka: the book reached the island well after the author's death, and was judged too difficult and not really useful by his surviving colleagues.

All the same, Ruëll's grammar is a rare publishing feat for a language other than Malay in the history of Dutch overseas linguistics. This publication may not have 
materialised at all if Witsen would not have acted as a patron. The foundational role of Witsen as a central hub between Asia and Europe cannot be overstressed. The key role of this colourful and prolific Amsterdam burgomaster in the circulation of various kinds of knowledge has been examined in a range of recent studies (see e.g. Peters 1989, 1994, 2010; Rietbergen 1985; Naarden 2010; Vermeulen 2015 , p. 96-98, to mention just a few). This extremely well-connected scholar used his position and his wealth to sponsor studies of talented young men such as Herbert de Jager, who were expected to return the favour later by sending back drawings, manuscripts, naturalia and other objects, along with scholarly and scientific information. His late letters exchanged with Cuper contain questionnaires on various cultural and religious topics, which were forwarded to his friends and protégés. The following section will confirm the crucial position held by Witsen.

\section{HOW ARMCHAIR SCHOLARS AT EUROPEAN UNIVERSITIES BENEFITTED FROM THE VOC NETWORK}

So far, this paper has examined to what extent the VOC has stimulated or discouraged the making of linguistic materials, and it has outlined their fate in Europe. The present section will reverse the perspective, as it will try to investigate to what extent Europe-based scholars actively solicited VOC-actors and their network to enrich their knowledge about the languages of the world.

One of the reasons underlying the growing interest paid to the world's languages was the general belief, highly stimulated by Gottfried Wilhelm Leibniz, that languages were crucial (if not the sole) testimonials for uncovering the prehistory of mankind (see several contributions in Li 2014). After Conrad Gesner (1516-1565) had collected the Lord's Prayer in a limited number of languages in his 1555 Mithridates, this Biblical text has remained the default linguistic specimen for centuries - some criticisms on this choice were expressed from the late 18th century onwards (see Van Hal 2015 for further references). Hence, one can measure the expanding scope of the world's languages known to Early Modern scholars by studying the large number of collections of the Lord's Prayer printed between 1550 and 1750 . The following list is only a selection.

- Konrad Gesner. 1555. Mithridates.

- Bonaventura Vulcanius. 1597. De literis et lingua Getarum sive Gothorum.

- Hieronymus Megiser. 1603. Thesaurus Polyglottus.

- Ludekenius, Thomas. 1680. Oratio orationum.

- Witsen, Nicolaes. 1705. Noord en Oost Tartarye. 2nd ed.

- Chamberlayne, John (\& David Wilkins), eds. 1715. Oratio dominica in diversas omnium fere gentium linguas versa. 
- Benjamin Schultze \& Friedrich Fritz. 1748. Orientalisch-und Occidentalischer Sprachmeister.

To what extent did the activities and explorations undertaken by the VOC foster this collection of language specimens, whose number was steadily growing?

The 1680 collection, published in Berlin, was a remarkable one. Judging by the title page the volume draws on 'the most reliable authors', rather than on 'prior collections'. Moreover, each language, it says, has been rendered in its genuine characters. The volume's author, Andreas Müller Greiffenhagius (1630-1694), who in this book hid behind the pseudonym Thomas Ludekenius for reasons that were already unclear to his contemporaries, was a colourful figure in the 17 th-century Republic of letters (Noack 1995). Boasting of having discovered the secrets of the Chinese language, he desperately tried to sell his 'Chinese key' to the highest bidder. Compared to prior collections, Müller's compilation contained a number of new language specimens. In contrast to John Wilkins, who had included in an appendix to his renowned Essay Towards a Real Character (1668) new specimens such as Malagasy, Poconchi and the language of New England without specifying his sources (J. Wilkins 1668, p. 434), Müller duly acknowledged his informants. This is why we know that he relied for the Malay specimen on a 1629 transliteration by 'Johan van Hasel', which is a reference to Ruyl (1629) (see Ludekenius 1680, p. 22 and see Thianto 2014 for some background of this 1629 publication). For the inclusion of Tamil, Müller was indebted to the already mentioned Philippus Baldaeus. It was Baldaeus' uncle Robertus Junius (Robert de Jonghe, 16061655) who happened to be the informant behind the new Formosan or Taiwanese specimen included in the compilation. Here, however, Müller (Ludekenius 1680, p. 27) is far less clear about his source, as he only mentions the letters 'J. L.' - a somewhat frugal reference to the German scholar Hiob Ludolf, who was first and foremost a specialist in Ethiopian studies. Thanks to the detailed Ludolf biography (Juncker 1710, p. 44), both contemporary and present-day scholars have been able to reconstruct how this linguistic specimen ended up in Müller's collection (see for instance Leibniz 1768, p. 209-210 and Keevak 2004, p. 84-88). We now have first-hand testimony to confirm this account. The King's College London, Foyle Special Collections Library preserves an interleaved copy of Müller's 1680 Oratio orationum that has been extensively annotated by Ludolf himself (MS Marsden Collection B6/8). To the best of our knowledge, these Latin notes have never been studied in modern scholarship (see however Van Hal Forthc.). At the outset of the book, Ludolf lists the shortcomings of Müller's work ('defectus hujus opusculi'). One of its flaws, in Ludolf's opinion, was the lack of a clear reference to his own name as the source for the Formosan language specimen. The mere initials made it almost impossible for interested scholars, Ludolf continues, "to inquire where 
I had this specimen from, viz. from the Formosan Catechism of Junius, who as a missionary of the Formosans had lived for a long time in this Island, where he composed a Catechism for its population"8. Ludolf probably met Robert de Jonghe about 1650 in Delft. This Dutch protestant minister had been teaching and evangelising the native people of Taiwan for a long period (see Klöter 2008 and Meuwese 2010 for a general overview). Ludolf's annotated copy reveals that other Dutch informants had also helped him widen his linguistic horizon. On f. $82^{\mathrm{v}}$ he noted that "a certain Dutchman, returned from Suratta, reported that the following numbers were used in Hindostani, pronounced as follows: 1. êek; 2. do; 3. dîn; 4. ğiahar; 5. bânch; 6. chö/Tschö; 7. sât; 8. ât; 9. noh; 10. tēs. [...]"’. He added that these numbers "were written in an imperfect way", and he assigned some of these numbers $(1,2,4,5,7,9)$ with a letter $\mathrm{P}$ written in red ink, thus hinting at similarities with Persian.

Ludolf also played a major role in a transmission story on which much ink has been expended. His posthumous biography contains, as an appendix, a list of Khoi words with a Dutch and Latin translation (Juncker 1710, p. [229]-[237]). Leibniz' Collectanea etymologica (1717) contained a Khoi version of the Lord's Prayer (for a useful survey, see Fauvelle-Aymar 2002, p. 228-237 and Den Besten 2010). For both specimens, Witsen once again turns out to have been a crucial hub. Witsen's own skilful use of informants is best seen in his opus magnum (and rarissimum), Noord en Oost Tartarye, of which the second improved edition was published by Halma in Amsterdam in 1705. Along with a number of Lord's Prayers, this highly remarkable book (about which see Naarden 2010) incorporated word lists in over 25 languages of Central Asia, including Jakut, Samoyed, Mongolian, Georgian, Crimean, and Kalmuk (see Naarden 2004). A list of 143 Korean words, likely the first ones ever arrived in Europe, was provided to Witsen by Mattheus Eibokken, who as a surgeon survived a shipwreck when sailing from Formosa (Taiwan) to Nagasaki in August 1653 (see Vos 1975).

The following landmark in the history of collections of the Lord's Prayer was the intriguing, but as yet hardly explored, 1715 volume collected by John Chamberlayne (1666-1723) and edited by the then-young orientalist David Wilkins (1685-1745). The collection boasts about having almost doubled the number of specimens as well as about having improved the general method followed (Wilkins 1715, p. sig. **v; see also a 1713 letter from Chamberlayne to Leibniz as published in

8 "Formosanam (insulae Formosae prope Chinam) edidit, quam a me accepit, idque significant literae meae initiales I. L. oportebat eum exprimere meum nomen, ut talium studiosi ex me sciscitari potuissent, ubi acceperim nempe ex Catechismo Formosano Junii, qui Formosanorum Apostolus fuit, et diu in illa Insula vixit, atque Catechismum pro insulanis Lingua vernacula composuit" (MS Marsden Collection B6/8 f.1 $1^{v}$ ).

9 "Numeros sequentes in Hindostan usurpatos retulit Hollandus quidam Surattâ redux, et ita pronuntiabat [...]. Inperfecta scripta sunt ista. [...] P denotat Persicè." 
Zulaika Hernández 2009, p. 325). Wilkins' preface reveals that he received one of the Malay specimens from Valentijn's daughter Cornelia, who was, "hardly thirteen years old, endowed with an astonishing and even miraculous command of languages, primarily Malay, Latin, Portuguese and Dutch"10. In addition, Wilkins also mentions contributions by Petrus Croonenburgh and by painter and traveller Cornelis de Bruijn (1652-1727). In this connection, it can be pointed out that the widening of the linguistic scope also led to the discovery of ancient inscriptions composed in undeciphered languages. After De Bruijn arrived in 1704 in Persepolis accompanied by VOC-representative Adriaan de Backer, he sent a drawing of some Old Persian lines in cuneiform characters to the Netherlands. In 1709, Gijsbert Cuper transmitted a reproduction of the characters to Otto Sperlingius (1634-1715), adding that he would regard the man who was able to decipher these characters as a 'mighty Apollo'. He also pointed out that he agreed with Leibniz, who stated that the language hidden behind these characters must be of an age-old nature (Polenus 1737, p. 235).

All this suggests that the interest in non-European languages in Europe was motivated by historical rather than by theological concerns. The following remark by the theologian scholar August Pfeiffer (1634-1715) is revealing. After discussing a few Malay linguistic tools (posthumous editions contain a more extensive list with several 'VOC-grammars'), he concludes that it did not make much sense to go into more detail here, given that the usefulness of these Indian materials, if compared with the so-called oriental or 'Semitic' languages, for theologians is limited (Pfeiffer 1680 , p. 345$)^{11}$. Historical-oriented scholars, however, tended to have a more intrinsic interest in these non-European languages. In connection with the activities of the VOC, one scholar in particular must be mentioned in particular, although he definitely deserves a study in his own right. Adriaan Reland, who famously never left his native country, might have been the scholar who added a Roman transliteration in Johannes Ruëll's Singaleesche Taal-Kunst (see above). Not only did Reland know the publisher Halma very well, he also announced the grammar in his dissertation on the languages of eastern islands a few months before it was published (Relandus 1708, p. 81-82). This dissertation clearly reveals to what extent Reland was dependent on VOC-related informants, many of whom are mentioned (notably, the Java-based expert in Malay Cornelis Mutter - see Valentijn 17241726, p. 86; Reid 2014). In addition, the limited number of Reland's letters that

10 "alteram in multis a prima diversam, a Reverendi Viri Domini Francisci Valentini filia, Domina Cornelia Valentinia, quae vix tredecim annos nata mira Linguarum in primis Malaicae, Latinae, Lusitanicae et Belgicae notitia ad miraculum usque imbuta accepi. Magnopere miratus sum elegantes litteras nitidosque earum ductus [...]" (Wilkins 1715, p. ***3; see Damsté 1953 for further background).

11 Werndly (1740) makes a similar divide between the linguae orientales and linguae Indicae. 
have been preserved also testify to his interest in languages going beyond the classical linguae orientales (see Peters 1994, p. 32). But especially from the auction catalogue of his library, one can infer how rich his collection of grammatical and lexicographical manuscripts was (Relandt \& Reland 1761).

\section{OuTLOOK}

This paper has tried to cast light on the range of linguistic activities undertaken against the background of the VOC trade. We have seen that there is no evidence that the VOC direction has commissioned scholarly linguistic work (see e.g. Den Besten 2010, p. 267), whereas some fellowships were granted for botanical studies, which could directly help in keeping the VOC crew in good health (Baas 2002, p. 125), as well as for scientific studies. However, publications devoted to the natural sciences sometimes contained indirect linguistic information (see Leuker 2010 for an example, cf. also Hendrik van Rheede's (1636-1691) 1678 Hortus Malabaricus, containing several Sanskrit words). The linguistic work that was done was achieved to a large extent by Protestant ministers. The general lack of linguistic knowledge management and the VOC secrecy policy can at least partly explain why so many manuscripts were lost or stolen, why so many names have been erased, and why a number of works have been pirated or plagiarised. After Herbert de Jager's death in a Batavian weeshuijs, his rich linguistic legacy ('a treasure of learned notes') was liable to be neglected and ultimately to be lost as well. This prompted Witsen, with whose help this 'farmer's son from Swammerdam' was sent to Batavia, to remark that 'almost nobody [in Holland] was curious' enough to appreciate De Jager's linguistic genius (Gebhard 1881 II, p. 361; Peters 2010, p. 229-230). Witsen's note on De Jager's humble social background shows that a profound knowledge of non-European languages ceased to be the exclusive privilege of institutional scholars and that the VOC network had, albeit in a very limited and indirect degree, stimulated a tendency of democratisation of education. In turn, the very biography of Witsen illustrates to what degree the personal interests of the VOC direction could influence the importance that was attached to the acquisition and circulation of knowledge. In sum, the VOC did certainly not establish an 'anti-intellectual' policy as such, but only a minority of the VOC directors engaged in actively promoting scholarship.

It is therefore safe to state that the VOC has played a pivotal, albeit often only indirect, role in the circulation of Asia-related knowledge. Apart from the Catholic missionary endeavours, the East India Company was the only European organisation that possessed the necessary infrastructure that enabled Europeans to obtain first-hand information on Asia. The examples of the collections of the Lord's Prayer illustrate how the Dutch VOC network substantially helped increase the 
number of known world languages. To the best of our knowledge, however, not many scholars in the European Republic of Letters discussed the role VOC as an organisation had to play in stimulating knowledge about Asian languages. It seems that its commercial priorities were taken for granted, and that scholarly input was expected to be obtained from missionaries and actors operating in the shade of the VOC trade (See Werndly 1740, p. 654, quoting Mathurin Veyssière de la Croze).

\section{REFERENCES}

Baas, Pieter, 2002. "De VOC in Flora's lusthoven", Blussé and Ooms (2002), 124-137.

Bailly, Jean-Sylvain and Voltaire, 1777. Lettres sur l'origine des sciences, et sur celle des peuples de l'Asie [...], Londres \& Paris, Chez M. Elmesly.

Beekman, E. M, 1988. Fugitive dreams: an anthology of Dutch Colonial literature, Amherst, Mass., University of Massachusetts Press.

Bertrand, Romain, 2013. "The Making of a 'Malay Text': Peter Floris, Erpenius, and Textual Transmission In and Out of the Malay World at the Turn of the Seventeenth Century", Quaderni storici 142 (1), 141-166.

Brendecke, Arndt, and Susanne Friedrich, 2015. "Introduction", Friedrich et al., 1-18.

Blussé, Leonard, 2008. Visible cities. Canton, Nagasaki, and Batavia and the coming of the Americans, Cambridge, Massachusetts \& London, Harvard University Press.

Blussé, Leonard, and Ilonka Ooms (eds), 2002. Kennis en compagnie: de Verenigde OostIndische Compagnie en de moderne wetenschap, Amsterdam, Balans.

Chamberlayne, John, [and David Wilkins] (eds), 1715. Oratio dominica in diversas omnium fere gentium linguas versa et propriis cujusque linguae characteribus expressa. Una cum dissertationibus nonnullis de linguarum origine variisque ipsarum permutationibus, Amstelædami, Typis Guilielmi \& Davidis Goerei.

Damsté, H[enri] T[itus], 1953. "De slang in de steen en de twee Cornelia's Valentijn", Bijdragen tot de Taal-, Land-en Volkenkunde 109 (2), 164-179.

De La Croze, Mathurin Veyssière, 1724. Histoire du christianisme des Indes, La Haye, Vaillant \& N. Prevost.

Den Besten, Hans, 2010. "A badly harvested field: the growth of linguistic knowledge and the Dutch Cape Colony until 1796", Huigen et al., 267-294.

Fauvelle-Aymar, François-Xavier, 2002. L'invention du Hottentot: histoire du regard occidental sur les Khoisan, XVe-XIXe siècle, Paris, Publications de la Sorbonne.

Feenstra Kuiper, Jan, 1921. Japan en de buitenwereld in de achttiende eeuw, 's-Gravenhage, Nijhoff.

Fleischer, Alette, 2010. "(Ex)changing knowledge and nature at the Cape of Good Hope, circa 1652-1700", Huigen et al., 243-265.

Friedrich, Susanne, Arndt Brendecke, and Stefan Ehrenpreis (eds), 2015. Transformations of Knowledge in Dutch Expansion, Berlin \& Boston, De Gruyter.

Gaastra, Femme Simon, 2007. "The organization of the VOC." In The Archives of the Dutch East India Company (VOC) and the Local Institutions in Batavia (Jakarta), G. L. Balk, F. Van Dijk, and D. J. Kortlang eds, Leiden \& Boston, Brill, 13-27.

Gebhard, Johan Fredrik, 1881. Het leven van Mr. Nicolaas Cornelisz: Witsen (1641-1717), Utrecht, J.W. Leeflang [2 vols.].

Goodman, Grant K. 2000. Japan and the Dutch 1600-1853, Richmond, Surrey, Routledge.

Groeneboer, Kees, 1993. Weg tot het Westen. Het Nederlands voor Indië 1600-1950. Een taalpolitieke geschiedenis, Leiden, KITLV Uitgeverij.

—, 1998. Westerse koloniale taalpolitiek in Azië: het Nederlands, Portugees, Spaans, Engels en Frans in vergelijkend perspectief, Amsterdam, Koninklijke Nederlandse Akademie van wetenschappen. 
Groenewald, Gerald, 2004. "To Leibniz, from Dorha: A Khoi Prayer in the Republic of Letters", Itinerario 28 (01), 29-48.

Häberlein, Mark \& Alexander Keese (eds), 2010. Sprachgrenzen, Sprachkontakte, Kulturelle Vermittler: Kommunikation zwischen Europäern und Aussereuropäern (16.-20. Jahrhundert), Stuttgart, Steiner.

Huigen, Siegfried, 2007. Verkenningen van Zuid-Afrika: achttiende-eeuwse reizigers aan de Kaap, Zutphen, Walburg Pers.

-, 2009. Knowledge and Colonialism: Eighteenth-Century Travellers in South Africa, Leiden \& Boston, Brill.

—, 2010. "Introduction", Huigen et al., 1-17.

Huigen, Siegfried, Jan L. de Jong, and Elmer Kolfin (eds), 2010. The Dutch Trading Companies As Knowledge Networks, Leiden \& Boston, Brill.

Juncker, Christian, 1710. Commentarius de Vita, scriptisque ac meritis illustr. viri Jobi Ludolf [...] in appendice adiectae sunt tum epistolae aliquot clarorum virorum, tum etiam, specimen linguae Hottentotticae, Lipsiae et Francofurti, Sumtibus Joh. Friderici Braunii.

Keevak, Michael, 2004. The Pretended Asian: George Psalmanazar's Eighteenth-century Formosan Hoax, Detroit, Wayne State University Press.

Klöter, Henning, 2008. "Facts and fantasy about Favorlang: Early European encounters with Taiwan's languages", Studies in Slavic and General Linguistics 33, 207-223.

Kolbe, Peter, 1727. Naaukeurige en uitvoerige Beschryving van de Kaap de goede Hoop [...], Amsterdam, Balthazar Lakeman.

Landwehr, John H., Peter van der Krogt, Charles Ralph Boxer, and Günter G. Schilder, 1991. VOC: a bibliography of publications relating to the Dutch East India Company: 1602-1800, Utrecht, HES.

Leibniz, Gottfried Wilhelm, 1768. Opera omnia. Tomus sextus, in duas partes distributus, quarum I. continet philologicorum continuationem, II. collectanea etymologica, ed. Ludovicus Dutens, Genevae, apud fratres De Tournes.

Leuker, Maria-Theresia, 2010. "Knowledge transfer and cultural appropriation: Georg Everhard Rumphius's 'D'Amboinsche Rariteitkamer' (1705)”, Huigen et al., 145-170.

Li, Wenchao, (ed.), 2014. Einheit der Vernunft und Vielfalt der Sprachen - Beiträge zu Leibnizens Sprachforschung und Zeichentheorie, Stuttgart, Steiner.

Lombard, Denis, 2001. "À propos d'un manuscrit oublié de Herbert de Jager (1683)", Fruits of inspiration: studies in honour of Prof. J.G. de Casparis [...] on the occasion of his 85th birthday, Marijke J. Klokke and Karel R. van Kooij eds, Groningen, Forsten, 243-255.

Ludekenius, Thomas, 1680. Oratio orationum. s s. Orationis Dominicae versiones praeter authenticam ferè Centum ..., Berolini, Ex officina Rungiana.

Maier, Henk M. J., and Jan van der Putten, 2002. "Van tolken, papegaaien en predikanten: het Maleis en de VOC", Blussé and Ooms, 100-113.

Meuwese, Mark, 2010. "Language, Literacy and Education: Native Peoples and Dutch Protestant Missions in Southwestern Taiwan and Northeastern Brazil, 1624, 1662", Häberlein \& Keese, 107-130.

Naarden, Bruno, 2004. "Nicolaas Witsen en de Europese obsessie met talen in de zestiende en zeventiende eeuw", Het Babylonische Europa. Opstellen over veeltaligheid, Annemarie Van Heerikhuizen et al. eds, Amsterdam, Amsterdam University Press, 21-40.

—, 2010. "Witsen's studies of Inner Eurasia", Huigen et al., 211-239.

Neill, Stephen, 2004. A History of Christianity in India: The Beginnings to AD 1707, Cambridge, Cambridge University Press.

Noack, Lothar, 1995. "Der Berliner Propst, Orientalist und Sinologe Andreas Müller (1630-1694). Ein bio-bibliographischer Versuch", Nachrichten der Gesellschaft für Natur- und Völkerkunde Ostasiens (NOAG), 157-158, 119-158.

Paranavitana, K. D., 2013. The Dutch Sinhala Dictionary by Simon Cat, Colombo, The Department of National Archives, Sri Lanka. 
Peters, Marion, 1989. "Nicolaes Witsen and Gijsbert Cuper: two seventeenth-century Dutch Burgomasters and their Gordian knot", Lias. Sources and documents relating to the Early Modern History of Ideas 16 (1), 111-151.

—, 1994. "From the study of Nicolaes Witsen (1641-1717). His life with books and manuscripts", Lias. Sources and documents relating to the Early Modern History of Ideas 21, 1-47.

—, 2010. De wijze koopman: het wereldwijde onderzoek van Nicolaes Witsen (1641-1717), burgemeester en VOC-bewindhebber van Amsterdam, Amsterdam, Bert Bakker.

Pfeiffer, August, 1680. Critica sacra, Dresdae, Impensis Mart. Gabriel. Hübneri, excudebat Vidua Bergeniana.

Polenus, Joannes (ed.), 1737. Utriusque thesauri antiquitatum Romanarum Graecarumque nova supplementa, Venetiis, Pasquali.

Pytlowany, Anna, 2014. “'You don't see what you don't know': examining material aspects of manuscripts (Part I)", History and Philosophy of the Language Sciences. Available at: http://hiphilangsci.net/2014/09/17/you-dont-see-what-you-dont-know-examiningmaterial-aspects-of-manuscripts-part-i.

—, 2015. "Examining material aspects of manuscripts. Part II: Bindings and provenance", History and Philosophy of the Language Sciences. Available at: http://hiphilangsci. net/2015/02/25/examining-material-aspects-of-manuscripts-part-ii-bindings-and-provenance.

-. Forthc. PhD-Dissertation, Universiteit van Amsterdam.

Pytlowany, Anna and Zwartjes, Otto. Forthc. "Pre-modern descriptions in Dutch of languages in India: Ketelaar's grammar of Hindustani and Persian (1698) and Rüell's grammar of Sinhala (1699)".

Reid, Anthony, 2014. "Indonesian manuscripts in the Vatican Library", Southeast Asia Library Group (SEALG) newsletter 46, 51-60.

Relandt, Jan Hubert and Adriaan Reland, 1761. Naam-lyst van een zeer keurige verzameling [..] boeken [Veilingcatalogus], Utrecht, Kroon \& Tieme van Paddenburg.

Relandus, Adrianus, 1708. Dissertationum miscellanearum pars tertia, Trajecti ad Rhenum, ex off. G. Broedelet.

Rietbergen, Peter J. A. N., 1985. "Witsen's World: Nicolaas Witsen (1641-1717) between the Dutch East India Company and the Republic of Letters", Itinerario 9 (2), 121-134.

—, 2002. "Wie verre reizen doet... Compagniesdienaren en andere schrijvende reizigers", Blussé and Ooms, 164-183.

Rutherford, Danilyn, 2005. "Frontiers of the lingua franca: Ideologies of the linguistic contact zone in Dutch New Guinea", Ethnos 70 (3), 387-412.

Ruyl, Albert Corneliszoon, 1629. Het Nievwe Testament [...] in Neder-duyts ende Malays, Enckhuysen, Jan Jacobsz Palensteyn.

Schouten, Maria Johanna, 2010. "Malay and Portuguese as Contact Languages in the Southeast Asian Archipelago, 16th-18th Centuries", Häberlein \& Keese, 345-354.

Stolz, Thomas and Ingo H. Warnke, 2015. "From missionary linguistics to colonial linguistics." In Colonialism and missionary linguistics, Klaus Zimmermann and Birte Kellermeier-Rehbein eds, Berlin \& München \& Boston, De Gruyter, 3-25.

Sutherland, Heather, 2010. "Treacherous Translators and Improvident Paupers: Perception and Practice in Dutch Makassar, Eighteenth and Nineteenth Centuries", Journal of the Economic and Social History of the Orient 53 (1/2), 319-356.

Thianto, Yudha, 2014. The Way to Heaven: Catechisms and Sermons in the Establishment of the Dutch Reformed Church in the East Indies, Eugene, OR Wipf and Stock Publishers.

Twidle, Hedley, 2013. "Writing the Company: From VOC Daghregister to Sleigh's Eilande", South African Historical Journal 65 (1), 125-152.

Valentijn, François, 1724-1726. Oud en nieuw Oost-Indiën, Dordrecht, Joannes van Braam.

Van Berkel, Klaas, 1998. Citaten uit het boek der natuur: opstellen over Nederlandse wetenschapsgeschiedenis, Amsterdam, Bert Bakker. 
Van Dam, Pieter, 1927-1954. Beschryvinge van de Oostindische Compagnie, 1639-1701, ed. by F. W. Stapel \& Carel Wessel Theodorus van Boetzelaer van Asperen en Dubbeldam, 's-Gravenhage, Martinus Nijhoff.

Van Hal, Toon, 2015. "Friedrich Gedike on why and how to compare the world's languages: A stepping stone between Gottfried Wilhelm Leibniz and Wilhelm von Humboldt?", Beiträge zur Geschichte der Sprachwissenschaft 25, 53-76.

- Forthc. "Ludolf and the languages of the world".

Van Renssen, Henk, 2002. "Alleen gelt, geen wetenschap soeken onse luyden", De Volkskrant. Available at: http://www.volkskrant.nl/archief/alleen-gelt-geen-wetenschapsoeken-onse-luyden a636327/ [Accessed July 6, 2015].

Vermeulen, Han F., 2015. Before Boas: the genesis of ethnography and ethnology in the German Enlightenment, Lincoln \& London, University of Nebraska Press.

Vos, Frits, 1975. "Master Eibokken on Korea and the Korean Language: Supplementary Remarks to Hamel's Narrative", Transactions of the Korea Branch of the Royal Asiatic Society L, 7-42.

Werndly, Georgius Henricus, 1740. "Oratio inauguralis, de linguarum orientalium et Indicarum cognitione necessaria theologo ad Indos profecturo", Tempe Helvetica: Dissertationes atque observationes theologicas, philologicas, criticas, historicas, exhibens (vol 4, 4), Tiguri, ex officina Heideggeriana, 617-662. [First published in Amsterdam, 1737]

Wilkins, David, 1715. “[Praefatio]”, John Chamberlayne and David Wilkins eds.

Wilkins, John, 1668. An Essay Towards a Real Character, And a Philosophical Language, London, Gellibrand.

Willemyns, Roland, 2013. Dutch: Biography of a Language, Oxford, Oxford University Press.

Zulaika Hernández, Josu M., 2009. "Nuevos datos sobre las obras vascas de Pierre d'Urte." Estudios de Lingüistica de la Universidad de Alicante 23, 315-350. 
